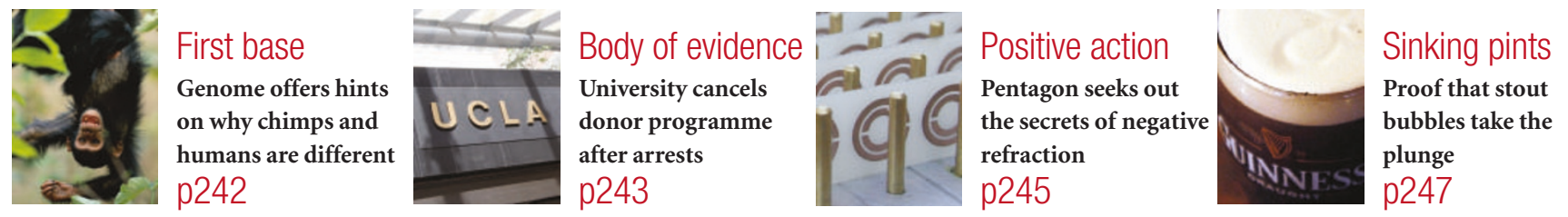

\title{
Battle lines are drawn as French researchers resign en masse
}

\section{Declan Butler, Paris}

A thundering roar went up from thousands of researchers gathered outside the city hall in Paris on 9 March. Leaders of a scientific revolt emerged to announce that more than 2,000 lab heads meeting inside had voted overwhelmingly to resign in protest at the government's handling of research.

The news was a massive boost for the protest movement Save Research. The 72,000 signatories of the group's petition, launched in January, had promised to resign from any management duties unless the government met their demands. These included redressing a financial crisis in research, reinstating 550 full-time research posts that have been switched to short-term contracts, and launching a national debate on reforming French science (see Nature 428, 105;2004).

The vote to carry through the threat showed that senior members of the scientific establishment were prepared to act. "The struggle continues," says an exhilarated Alain Trautmann, a cell biologist at the Cochin Institute in Paris and spokesman for Save Research.

Resolve had hardened on the morning of the vote, when Prime Minister Jean-Pierre Raffarin gave a hardline interview with the newspaper Liberation in which he insisted that the government would not meet the protesters' demands. The subsequent show of strength far exceeded the protest organizers' expectations. Once fax and e-mail votes were counted, 1,280 lab heads and 1,958 team leaders had resigned. This amounts to more than half of the lab heads at both the CNRS, the country's largest research agency, and the biomedical research agency INSERM.

The move is largely symbolic in the short term, as the research-agency heads have two months to consider whether to accept the resignations. Bernard Larrouturou, CNRS director-general, has already convened a meeting with the protesters for 23 March.

In the meantime, researchers are setting up local committees to maintain the pressure, and Save Research has called for a national protest on 19 March. It has also asked young scientists and homesick French expatriates to inundate the research ministry with their CVs.

The resignations have opened up the

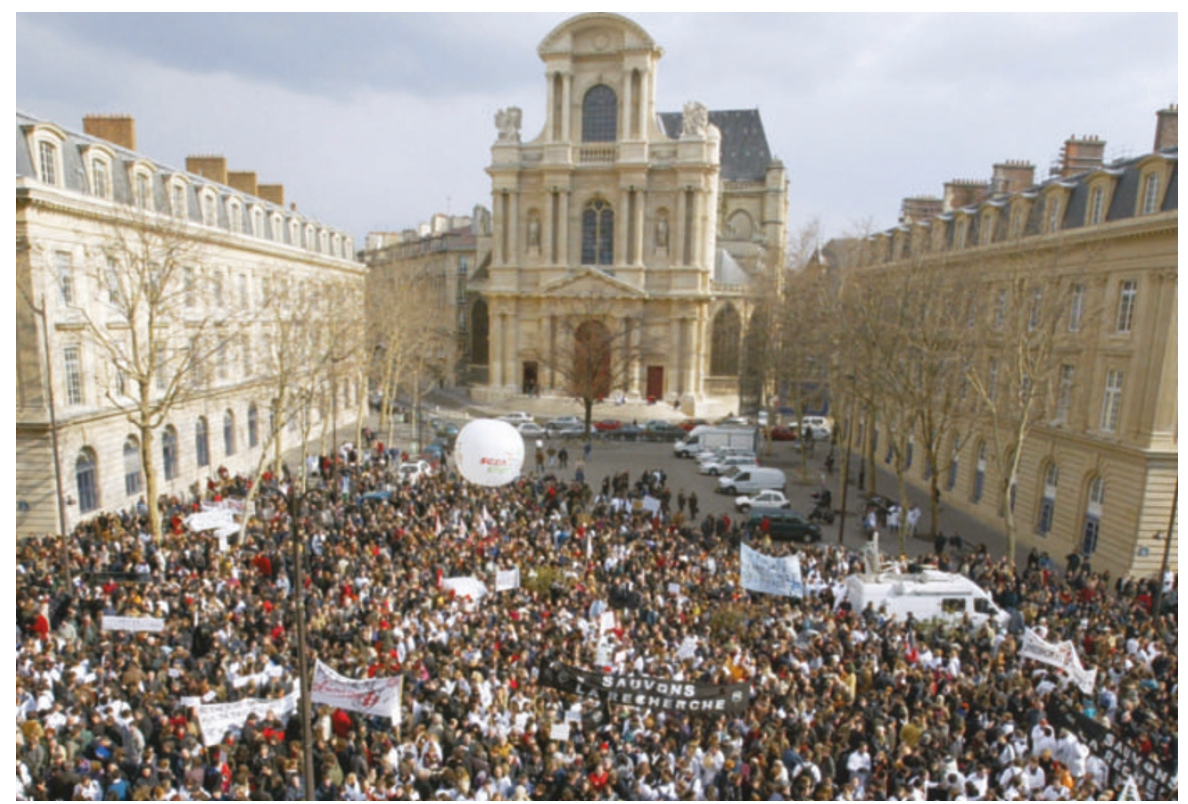

Solidarity: protesters rally on the streets of Paris as researchers vote to resign managerial duties.

debate about how to overhaul France's centralized and bureaucratic science system. The government was already planning to produce a white paper on the subject before the end of the year, but Save Research refused to cooperate with the consultation process, complaining that its views were not being represented.

This deadlock was broken last week when Save Research agreed to work with an independent committee set up to consult with French researchers and to feed their views into the white paper, and next year's science budget.

The 30-member committee, which will meet for the first time this week, will be cochaired by Étienne-Émile Baulieu and Édouard Brézin, president and vice-president, respectively, of the French Academy of Sciences. It will include nine members of Save Research and other leading French scientists, and aims to organize a whirlwind series of regional and national conferences.

The committee is unlikely to have to look far for suggestions on reform. Larrouturou, for instance, last week discussed plans for the CNRS in the press. He wants to channel resources into a smaller number of larger labs, to boost the number of foreign researchers in the agency's ranks from $12 \%$ to $25 \%$ and to make evaluation procedures tougher.

Meanwhile, four leading scientists set out their manifesto on 10 March. Biologist François Jacob and chemist Jean-Marie Lehn, Nobel laureates at the Collège de France in Paris, have worked with Philippe Kourilsky, director-general of the Pasteur Institute, and Pierre-Louis Lions, a mathematician at the University of Paris Dauphine, to draw up their unashamedly élitist vision. Importing many elements of the British and US research systems, their plan would decentralize the public research agencies, and over time devolve research to the French universities. "The crisis is open, and we must profit by reforming in depth," the manifesto's authors note.

More immediately, Save Research has called on President Jacques Chirac to intervene to create more posts for young scientists this year. Chirac has yet to reply, but with a recent poll suggesting that $82 \%$ of the French public support the scientists, the pressure is on for him to find a way out of the deadlock - especially in light of the regional elections that will be held at the end of March.

http://recherche-en-danger.apinc.org 